\title{
Kontribusi Gaya Belajar dan Motivasi Berprestasi Terhadap Kompetensi Pengetahuan IPA
}

\author{
L. G. Ika Yuliastini ${ }^{1}$, I K. Ngurah Wiyasa ${ }^{2}$, I. B. Surya Manuaba ${ }^{3}$ \\ ${ }^{123}$ Prodi Pendidikan Guru Sekolah Dasar, FIP \\ Universitas Pendidikan Ganesha, \\ Singaraja, Indonesia \\ e-mail: gede.ika.yuliastini@undiksha.ac.id'1 ,ngrh.wiyasa@undiksha.ac.id², \\ idabagussurya.manuaba@undiksha.ac.id ${ }^{3}$
}

\begin{abstract}
Abstrak
Penelitian ini bertujuan untuk mengetahui pengaruh signifikan gaya belajar dan motivasi berprestasi terhadap kompetensi pengetahuan IPA kelas V SD Negeri Gugus Ki Hajar Dewantara Kecamatan Denpasar Timur. Jenis penelitian ini adalah penelitian ex post facto, dengan jenis studi korelasional. Populasi penelitian ini adalah seluruh siswa kelas V SD Negeri Gugus Ki Hajar Dewantara sebanyak 214 siswa. Pengambilan sampel menggunakan teknik proportional random sampling dengan taraf signifikan 5\% sehingga diperoleh sampel dengan jumlah 135 siswa. Data penelitian dikumpulkan dengan metode nontes yaitu dengan instrumen angket gaya belajar dan motivasi berprestasi. Sedangkan data kompetensi pengetahuan IPA diperoleh dari pencatatan dokumen.Data hasil penelitian dianalisis dengan metode analisis regresi linier sederhana dan analisis linier ganda. Hasil analisis regresi ganda diperoleh $F_{\text {hitung }}=9,30>F_{\text {tabel }}=3,07$. Ini berarti terdapat pengaruh yang signifikan gaya belajar dan motivasi berprestasi terhadap kompetensi pengetahuan IPA kelas V SD Negeri Gugus Ki Hajar Dewantara Kecamatan Denpasar Timur Tahun Ajaran 2018/2019. Hasil analisis diperoleh $\mathrm{R}^{2}=0,123$ dan kontribusinya sebesar $12,3 \%$. Ini menunjukkan bahwa tidak hanya gaya belajar dan motivasi berprestasi yang mempengaruhi kompetensi pengetahuan IPA, namun terdapat faktor lain dari dalam maupun luar diri siswa yang mempengaruhi kompetensi pengetahuan IPA sebesar 87,7\%.
\end{abstract}

Kata Kunci: ipa, gaya belajar, motivasi berprestasi

\begin{abstract}
The aimed of this research was to know the significant effect between learning style and achievement motivation toward natural science knowledge competency on fifth grade students of SD Negeri cluster Ki Hajar Dewantara of east Denpasar. The type of this research was ex post facto with correlational study type. The population was 214 students on fifth grade students of SD Negeri cluster Ki Hajar Dewantara. The sample was chosen by proportional random sampling technique with 5\% signifcant level and the 135 students were selected as the samples. The research data was collected by non-test method by using questionnaires of learning style and achievement motivation. Meanwhile, natural science knowledge competency was obtained from document recording. There were four prerequisite tests in this research. The data were analyzed by testing the simple linear regression and multiple linear regressions. The multiple linear regressions obtained $F_{\text {count }}=9,30>F_{\text {table }}=3,07$ and showed that the significant effect between learning style and achievement motivation toward natural science knowledge competency on fifth grade students of SD Negeri cluster Ki Hajar Dewantara of east Denpasar in academic year 2018/2019. The result of the analysis obtained $R^{2}=0,123$ with $12,3 \%$ contribution. The result showed that the natural science knowledge competency was not only influenced by learning style and achievement motivation, but also 87,7\% by students' internal and external factors.
\end{abstract}

Keywords: natural science, learning style, achievement motivation

\footnotetext{
*Corresponding author.

Received 20 January 2020, Accepted 20 March 2020; Available online 5 Appril 2020 (C) 2020 MI All Rights Reserved
} 


\section{Pendahuluan}

Pendidikan menjadi salah satu sarana penting untuk meningkatkan kualitas sumber daya manusia (SDM) dalam mendukung pembangunan suatu bangsa. Menurut Undang-Undang Nomor 20 Tahun 2003 tentang Sistem Pendidikan Nasional Bab I Pasal 1, pendidikan adalah usaha sadar dan terencana untuk mewujudkan suasana belajar dan proses pembelajaran agar peserta didik secara aktif mengembangkan potensi dirinya untuk memiliki kekuatan spiritual keagamaan, pengendalian diri, kepribadian, kecerdasan, akhlak mulia, serta keterampilan yang diperlukan dirinya, masyarakat, bangsa, dan negara. Secara garis besar, pendidikan bisa ditempuh melalui pendidikan formal dan pendidikan non formal. Pendidikan formal bisa didapat dengan mengikuti program pendidikan yang dirancang oleh pemerintah seperti sekolah maupun universitas. Sedangkan pendidikan non formal yaitu pendidikan yang bisa didapat dengan cara belajar sendiri melalui berbagai sumber (buku bacaan, pengalaman sendiri maupun orang lain) tanpa terikat dengan lembaga bentukan pemerintah. Ini menunjukkan bahwa pendidikan tersebut dapat ditempuh dimana saja dan kapan saja, salah satunya seperti yang disebutkan tadi yaitu di sekolah. Pendidikan di sekolah memiliki tujuan untuk mengubah perilaku siswa melalui proses pembelajaran sehingga siswa memiliki pengetahuan atau keterampilan tertentu. Hal yang paling pokok dalam tercapainya tujuan pendidikan di sekolah adalah proses belajar yang dialami oleh siswa sebagai anak didik.

Belajar ialah suatu proses usaha yang dilakukan seseorang untuk memperoleh suatu perubahan tingkah laku yang baru secara keseluruhan, sebagai hasil pengalamannya sendiri dalam interaksi dengan lingkungannya (Slameto, 2010). Untuk mencapai keberhasilan belajar ini tentunya harus didukung dengan berbagai faktor. Faktor-faktor yang mempengaruhi belajar banyak jenisnya tetapi dapat digolongkan menjadi dua golongan saja, yaitu faktor intern dan faktor ekstern (Slameto, 2010). Faktor intern yaitu faktor yang berasal dari dalam diri seseorang yang sedang belajar, sedangkan faktor ekstern adalah faktor yang berasal dari luar diri seseorang.

Faktor intern meliputi faktor jasmaniah (faktor kesehatan dan cacat tubuh) dan faktor psikologis (intelegensi, perhatian, minat, bakat, motivasi, kematangan, kesiapan). Faktor ekstern meliputi faktor keluarga (cara orangtua mendidik, relasi antaranggota keluarga, suasana rumah, keadaan ekonomi keluarga, pengertian orangtua, latar belakang kebudayaan), faktor sekolah (metode mengajar, kurikulum, relasi guru dengan siswa, relasi siswa dengan siswa, disiplin sekolah, alat pelajaran, waktu sekolah, standar pelajaran di atas ukuran, keadaan gedung, metode belajar, tugas rumah), dan faktor masyarakat (kegiatan siswa dalam masyarakat, mass media, teman bergaul, bentuk kehidupan masyarakat). Proses belajar pada jenjang sekolah dasar dijadikan sebagai pondasi dan sebuah bekal dasar pengembangan kehidupan, serta menjadi bekal dalam melanjutkan pendidikan di jenjang yang lebih tinggi. Untuk itu sudah seharusnya siswa menguasai semua kompetensi pengetahuan secara optimal. Salah satu kompetensi pengetahuan yang harus dikuasai siswa yaitu IImu Pengetahuan Alam (IPA). Kompetensi dapat diartikan sebagai kemampuan siswa dalam melaksanakan tugas atau pekerjaan. Mulyasa (2006:37) menyatakan bahwa, "Kompetensi merupakan perpaduan dari pengetahuan, keterampilan, nilai dan sikap yang direfleksikan dalam kebiasaan berpikir dan bertindak". Yaumi (2013: 84) menyatakan bahwa, "Kompetensi disimpulkan sebagai kemampuan untuk untuk melakukan suatu tugas tertentu secara efektif, jelas dan teratur". Pengetahuan adalah kemahiran dan pemahaman terhadap sejumlah informasi dan ide-ide (Susanto, 2014: 25). Kurniasih (2016: 68) menyatakan bahwa terdapat empat dimensi pengetahuan yakni sebagai berikut, 1) Pengetahuan faktual adalah pengetahuan dasar yang harus diketahui siswa sehingga siswa mampu memahami suatu masalah atau memecahkan masalah tersebut. 2) Pengetahuan konseptual adalah pengetahuan-pengetahuan dasar yang saling berhubungan dan dengan struktur yang lebih besar sehingga dapat digunakan secara bersama-sama. 3) Pengetahuan prosedural adalah pengetahuan mengenai bagaimana untuk melakukan sesuatu; metode untuk mencari sesuatu, suatu pengetahuan yang mengutamakan kemampuan, algoritma, teknik dan metode. 4) Pengetahuan metakognisi adalah pengetahuan yang melibatkan pengetahuan yang melibatkan pengetahuan kognisi secara umum. 
Berdasarkan uraian tersebut dapat disimpulkan bahwa kompetensi pengetahuan merupakan kemampuan siswa dalam menguasai suatu kemahiran atau melakukan suatu tugas tertentu secara efektif, jelas dan teratur dalam proses pembelajaran. Kompetensi pengetahuan menjadi salah satu kompetensi inti yang terdapat pada kurikulum 2013. Kompetensi pengetahuan juga dapat dinyatakan sebagai kompetensi pada ranah kognitif yang mampu mengukur tingkat penguasaan yang meliputi kegiatan mengingat (remembering), memahami (understanding), menerapkan (applying), menganalisis (analyzing), menilai (evaluating) dan mencipta (creating). Anderson (dalam Kosasih, 2012: 21) menguraikan keenam kategori atau taksonomi tersebut yakni sebagai berikut, 1) Mengingat adalah kompetensi yang paling mendasar dalam ranah kognitif. Kompetensi mengingat ditandai oleh kemampuan peserta didik untuk mengenali kembali sesuatu objek, ide, prosedur, prinsip, atau teori yang pernah diketahuinya dalam proses pembelajaran, tanpa memanipulasikannya dalam bentuk atau simbol lain. 2) Memahami dapat juga disebut dengan istilah "mengerti". Kompetensi ini ditandai oleh kemampuan peserta didik untuk mengerti akan suatu konsep, rumus, ataupun fakta-fakta untuk kemudian menafsirkan dan menyatakannya kembali dengan kata-kata sendiri. 3) Menerapkan merupakan kemampuan melakukan atau mengembangkan sesuatu sebagai wujud dari pemahaman konsep tertentu. 4) Menganalisis merupakan kemampuan memisahkan suatu fakta atau konsep ke dalam beberapa komponen dan menghubungkan satu sama lain untuk memperoleh pemahaman atas konsep tersebut secara utuh. 5) Mengevaluasi adalah kemampuan di dalam menunjukkan kelebihan dan kelemahan sesuatu berdasarkan kriteria atau patokan tertentu. 6) Mencipta merupakan kemampuan ideal yang seharusnya dimiliki oleh seorang peserta didik setelah mempelajari kompetensi tertentu. la tidak sekedar tahu, tetapi lebih dari itu, ia bisa melakukannya.

IPA merupakan ilmu yang mempelajari tentang konsep hidup yang harmonis dengan alam melalui berbagai kegiatan ilmiah. IPA menjadi salah satu mata pelajaran pokok dalam kurikulum pendidikan di Indonesia. Susanto (2013: 167) menyatakan bahwa, "Sains atau IPA adalah usaha manusia dalam memahami alam semesta melalui pengamatan yang tepat pada sasaran, serta menggunakan prosedur, dan dijelaskan dengan penalaran sehingga mendapatkan suatu kesimpulan". Wisudawati \& Sulistyowati (2015: 22) "IPA merupakan rumpun ilmu, memiliki karakteristik khusus yaitu mempelajari fenomena alam yang faktual (factual), baik berupa kenyataan (reality), atau kejadian (events) dan hubungan sebab akibatnya". Sedangkan Carin \& Sund (dalam Wisudawati \& Sulistyowati 2015: 24) mendefinisikan IPA sebagai "pengetahuan yang sistematis dan tersusun secara teratur, berlaku umum (universal), dan berupa kumpulan data hasil observasi dan eksperimen". Dari pemaparan para ahli dapat disimpulkan bahwa IPA merupakan ilmu yang mempelajari fenomena alam melalui observasi, pengamatan dan eksperimen untuk mendapatkan suatu kesimpulan. Jadi, kompetensi pengetahuan IPA adalah kemampuan siswa dalam menguasai ilmu yang mempelajari fenomena alam baik fakta maupun konsep melalui observasi, pengamatan dan eksperimen secara efektif, jelas dan teratur dengan jenjang kemampuan berpikir mengingat, memahami, menerapkan, menganalisis, mengevaluasi dan mencipta.

Selama ini banyak siswa yang menganggap bahwa mata pelajaran IPA adalah mata pelajaran yang sulit. Hal ini terbukti dari hasil perolehan Ujian Akhir Sekolah (UAS) yang dilaporkan oleh Depdiknas masih sangat jauh dari standar yang diharapkan (Susanto, 2013). Hal ini disebabkan karena dalam proses pembelajaran di sekolah guru hanya menjelaskan materi dengan metode ceramah yang membuat siswa cepat merasa bosan dan akhirnya tidak mendengarkan penjelasan guru, dalam hal ini guru harus memiliki cara-cara, strategi, dan pendekatan yang digunakan pada proses pembelajaran agar siswa lebih mudah dalam memahami untuk mencapai tujuan pembelajaran. Salah satu yang harus diketahui guru yaitu gaya belajar siswa. Gaya belajar pada umumnya merupakan suatu cara bagi individu untuk menyerap, mengatur, dan mengolah informasi yang diterima. Gaya belajar adalah kombinasi dari bagaimana siswa menyerap, lalu mengatur, dan mengolah informasi (DePorter \& Hernacki, 2016). Gaya belajar adalah bagaimana cara seseorang menyerap, mengatur informasi kemudian mengolahnya serta memanifestasikan dalam wujud nyata perilaku hidupnya (Ula, 2013). Gaya belajar merupakan kombinasi dari menyerap informasi, memproses sampai 
dengan mengolah informasi (Rhamdan, 2013). Setiap anak memiliki gaya belajar yang berbeda, tetapi tidak menutup kemungkinan ada juga yang memiliki gaya belajar yang sejenis. Gaya belajar yang tepat dapat menjadi kunci keberhasilan siswa dalam menerima pelajaran di sekolah. Gaya belajar dikelompokkan menjadi tiga yaitu gaya belajar visual, gaya belajar auditoral dan gaya belajar kinestetik (Deporter \& Hernacki, 2016). Gaya belajar visual yaitu gaya belajar dengan cara melihat, gaya belajar auditoral yaitu gaya belajar dengan cara mendengarkan sedangkan gaya belajar kinestetik yaitu gaya belajar dengan cara bergerak, bekerja dan menyentuh. Berdasarkan penjelasan tersebut dapat disimpulkan bahwa gaya belajar merupakan cara siswa dalam menyerap, mengatur, dan mengolah informasi dalam proses pembelajaran. Tidak semua siswa mempunyai gaya belajar yang sama. Kemampuan siswa untuk memahami dan menyerap pelajaran berbeda tingkatnya, ada yang cepat, sedang dan ada pula yang lambat. Bagaimanapun gaya belajar siswa itulah cara terbaik mereka untuk menyerap materi pelajaran dan mencapai tujuan pembelajaran dengan optimal. Dengan gaya belajar yang sesuai dengan siswa dan metode pembelajaran guru yang tepat dalam menyampaikan materi di kelas dapat mempengaruhi siswa untuk lebih bersemangat mengikuti pembelajaran. Gaya belajar yang kurang tepat dikhawatirkan akan mempersulit siswa dalam menerima, menyerap dan mengolah informasi yang diberikan guru sehingga akan banyak memakan waktu pembelajaran. Maka dari itu guru harus memperhatikan gaya belajar siswa yang berbeda-beda, apabila guru memperhatikan cara guru mengajar dan memperhatikan gaya belajar siswa maka siswa akan bersemangat, antusias dan termotivasi untuk mengikuti kegiatan pembelajaran di kelas.

Penyebab lain yang membuat nilai mata pelajaran IPA rendah yaitu karena sebagian besar siswa hanya berusaha menghafal materi pada setiap kali akan diadakan tes atau ulangan. Marjono (dalam Susanto 2013:167) untuk anak jenjang sekolah dasar "hal yang harus diutamakan adalah bagaimana mengembangkan rasa ingin tahu dan daya berpikir kritis mereka terhadap suatu masalah". Dalam mengembangkan rasa ingin tahu dan daya berpikir kritis ini, harus dimulai dari keinginan siswa itu sendiri. Dorongan atau keinginan dari dalam diri seseorang dikenal dengan istilah motivasi. Motivasi adalah dorongan dasar yang menggerakkan seseorang bertingkah laku (Uno, 2016). Baharuddin \& Wahyuni (2010: 23) menyatakan bahwa, "dari sudut sumbernya, motivasi dibagi menjadi dua, yaitu motivasi intrinsik dan motivasi ekstrinsik". Motivasi intrinsik memiliki pengaruh yang lebih efektif, karena motivasi intrinsik relatif lebih lama dan tidak tergantung pada motivasi dari luar (ekstrinsik). Adanya keinginan untuk mencapai prestasi termasuk dalam motivasi intrinsik. Susanto (2018:29) menyatakan bahwa, "Motivasi merupakan suatu dorongan, kekuatan, keinginan yang terdapat dalam diri siswa, yang menyebabkan siswa bertindak atau berbuat, sehingga motivasi berprestasi yang tinggi mendorong siswa untuk fokus pada pencapaian prestasi. Dalam proses belajar, motivasi berprestasi sangatlah penting dimiliki oleh siswa. Motivasi berprestasi sendiri merupakan dorongan yang dimiliki siswa untuk mengerjakan sesuatu dengan sebaik mungkin untuk mencapai tujuan yang diharapkan. Susanto (2018:35) menyatakan bahwa, "motivasi berprestasi merupakan suatu dorongan dalam diri individu untuk melakukan aktivitas dalam rangka mengusahakan kesuksesan atau memperoleh hasil sebaik-baiknya berdasarkan standar kesempurnaan dengan segenap potensi dan dukungan yang dimiliki”.

Penelitian ini bertujuan untuk mengetahui pengaruh yang signifikan gaya belajar terhadap kompetensi pengetahuan IPA kelas V SD Negeri Gugus Ki Hajar Dewantara Kecamatan Denpasar Timur Tahun Ajaran 2018/2019, untuk mengetahui pengaruh yang signifikan motivasi berprestasi terhadap kompetensi pengetahuan IPA kelas V SD Negeri Gugus Ki Hajar Dewantara Kecamatan Denpasar Timur Tahun Ajaran 2018/2019 dan untuk mengetahui pengaruh yang signifikan untuk dapat dilanjutkan mencari besaran kontribusi gaya belajar dan motivasi berprestasi terhadap kompetensi pengetahuan IPA kelas V SD Negeri Gugus Ki Hajar Dewantara Kecamatan Denpasar Timur Tahun Ajaran 2018/2019. 


\section{Metode}

Penelitian ini dilaksanakan dengan menggunakan rancangan penelitian evaluatif dengan hampiran kuantitatif deskriptif. Rancangan ini dipilih dengan pertimbangan untuk mengevaluasi program Program Pendidikan Anak Usia Dini (PAUD).

Model evaluasi yang digunakan adalah model CIPP. Model evaluasi CIPP adalah model evaluasi yang tujuannya untuk mengambil keputusan dalam merencanakan, melaksanakan, dan mengembangkan suatu program (Fuddin, 2007). Mbulu (1995: 62) model CIPP merupakan singkatan (akronim) dari contect evaluation, input evaluation, process evaluation, dan product evaluation.

Penelitian ini dilaksanakan di delapan (8) TK di Kecamatan Seririt dilaksanakn dari bulan Desember 2019, data diambil pada minggu kedua bulan Maret 2020. Total populasi penelitian yang terdiri dari kepala sekolah, guru, staf pegawai, dan ketua komite/Yayasan adalah 144 orang, dengan metode purposive sampling yang jumlah sampelnya dihitung dengan Nomogram Harry King yaitu $70 \%$ dari jumlah populasi menjadi 101, untuk menghindari bias data diambil sampel 105. Subjek penelitian CIPP ditunjukkan pada Tabel 01.

Tabel 01.

Subjek Penelitian CIPP

\begin{tabular}{clcc}
\hline No & \multicolumn{1}{c}{ Subjek Penelitian } & Populasi & Sampel \\
\hline 1 & Kepala Sekolah & 29 & 22 \\
2 & Guru & 63 & 45 \\
3 & Pegawai & 23 & 17 \\
4 & Ketua komite/yayasan & 29 & 21 \\
\hline & Jumlah & $\mathbf{1 4 4}$ & $\mathbf{1 0 5}$ \\
\hline
\end{tabular}

Instruman utama yang digunakan dalam penelitian ini adalah lembar kuesioner yang didukung dengan data observasi dan wawancara. Kuesioner dalam penelitian ini bersifat tertutup karena telah disediakan jawaban, sehingga responden tinggal memilih salah satu dari altrnatif jawaban yang dipilihnya sesuai dengan kondisinya. Kuesioner yang digunakan telah dilakukan uji ahli, serta uji coba validitas dan reliabilitas lapangan, diperoleh dari 127 butir pernyataan dalam kuesioner, tidak valid satu sehingga digunakan 126 butir pernyataan. Data dianalisis dengan statistik deskriptif dan evaluasi CIPP menggunakan transformasi data ke T skor kemudian dimasukkan ke dalam kuadran Glickman untuk mengetahui efektivitas implementasi SPMI di SMKN 3 Singaraja (Agung, 2016: 17-76; Agung \& Koyan, 2016: 37).

\section{Hasil dan Pembahasan}

Pengujian hipotesis pertama dengan analisis regresi linier sederhana diperoleh persamaan $\hat{Y}=55,54+0,27 X$ signifikan dan linier. Persamaan regresi yang telah didapat berarti setiap kenaikan 1 skor gaya belajar akan menyebabkan kenaikan 0,27 nilai kompetensi pengetahuan IPA pada konstanta 55,54. Hasil analisis data menyatakan $F_{\text {hitung }}=5,55>F_{\text {tabel }}=$ 3,92 , sehingga $\mathrm{H}_{0}$ ditolak yang berarti terdapat pengaruh yang signifikan gaya belajar terhadap kompetensi pengetahuan IPA kelas V SD Negeri Gugus Ki Hajar Dewantara Kecamatan Denpasar Timur Tahun Ajaran 2018/2019. Hasil analisis data diperoleh koefisien determinasi $\mathrm{R}^{2}=0,040$ dan kontribusinya sebesar $4 \%$. Jadi, gaya belajar berkontribusi terhadap kompetensi pengetahuan IPA siswa karena gaya belajar merupakan cara siswa dalam memperoleh dan mengolah informasi dalam pembelajaran, sehingga jika ketiga gaya belajar siswa dioptimalkan siswa akan lebih bersemangat dan tidak cepat merasa bosan dalam menerima pembelajaran dan pencapaian kompetensi pengetahuan IPA siswa dapat terus meningkat.

Pengujian hipotesis kedua dengan analisis regresi linier sederhana diperoleh persamaan $\hat{Y}$ $=52,01+0,32 X$ signifikan dan linier. Persamaan regresi yang telah didapat berarti setiap 
kenaikan 1 skor motivasi berprestasi akan menyebabkan kenaikan 0,32 nilai kompetensi pengetahuan IPA pada konstanta 52,01. Hasil analisis data menyatakan $F_{\text {hitung }}=11,08>F_{\text {tabel }}=$ 3,92, sehingga $\mathrm{H}_{0}$ ditolak yang berarti terdapat pengaruh yang signifikan motivasi berprestasi terhadap kompetensi pengetahuan IPA kelas V SD Negeri Gugus Ki Hajar Dewantara Kecamatan Denpasar Timur Tahun Ajaran 2018/2019. Hasil analisis data diperoleh koefisien determinasi $R^{2}=0,077$ dan kontribusinya sebesar $7,7 \%$. Jadi, motivasi berprestasi berkontribusi terhadap kompetensi pengetahuan IPA karena motivasi berprestasi merupakan dorongan dalam diri siswa untuk menyelesaikan tugas sebaik mungkin. Sehingga jika siswa memiliki dorongan atau keinginan dalam dirinya untuk mendapatkan hasil yang terbaik, pastinya siswa tersebut akan belajar dengan rajin untuk meningkatkan pencapaian kompetensinya dalam hal ini kompetensi pengetahuan IPA.

Pengujian hipotesis ketiga dengan analisis regresi linier ganda diperoleh persamaan $\hat{Y}=$ $26,711+0,287 X_{1}+0,331 X_{2}$ signifikan dan linier. Persamaan regresi yang telah didapat berarti setiap kenaikan 1 skor gaya belajar dan motivasi berprestasi akan menyebabkan kenaikan 0,287 dan 0,331 nilai kompetensi pengetahuan IPA pada konstanta 26,711 . Hasil analisis data menyatakan $F_{\text {hitung }}=9,30>F_{\text {tabel }}=3,07$, sehingga $H_{0}$ ditolak yang berarti terdapat pengaruh yang signifikan gaya belajar dan motivasi berprestasi terhadap kompetensi pengetahuan IPA kelas V SD Negeri Gugus Ki Hajar Dewantara Kecamatan Denpasar Timur Tahun Ajaran 2018/2019. Hasil analisis data diperoleh koefisien determinasi $R^{2}=0,123$ dan kontribusinya sebesar $12,3 \%$. Jadi, gaya belajar dan motivasi berprestasi berkontribusi terhadap kompetensi pengetahuan IPA karena jika gaya belajar siswa dioptimalkan dan motivasi berprestasinya terus dipacu hal tersebut akan membuat siswa tidak bosan dan lebih bersemangat dalam mengikuti pembelajaran dan membuat pencapaian kompetensi pengetahuan IPA terus meningkat.

Berdasarkan hasil yang sudah didapatkan, kontribusi gaya belajar dan motivasi berprestasi terhadap kompetensi pengetahuan IPA kelas V SD Negeri Gugus Ki Hajar Dewantara Kecamatan Denpasar Timur Tahun Ajaran 2018/2019 adalah sebesar 12,3\%. Hal ini menunjukkan bahwa tidak hanya gaya belajar dan motivasi berprestasi yang mempengaruhi kompetensi pengetahuan IPA, namun juga terdapat faktor-faktor lain yang mempengaruhi kompetensi pengetahuan IPA kelas V SD Negeri Gugus Ki Hajar Dewantara sebesar 87,7\%, baik itu faktor dari dalam diri siswa (intelegensi, sikap, gen dll) maupun dari luar diri siswa (hubungan sosial, pola asuh dll).

Pada penelitian ini menunjukkan bahwa gaya belajar dan motivasi berhubungan dengan kompetensi pengetahuan IPA. Pada dasarnya gaya belajar dikelompokkan menjadi tiga yaitu gaya belajar visual, auditorial dan kinestetik (Deporter \& Hernacki, 2016). Semua gaya belajar mempunyai kekuatan masing-masing. Dalam kenyataannya, kita semua memiliki ketiga gaya belajar tersebut, hanya saja biasanya satu gaya mendominasi. Guru dalam pembelajaran untuk mengetahui gaya belajar siswa dan melaksanakan pembelajaran yang bervariasi sehingga ketiga gaya belajar siswa dapat terayomi sehingga semua siswa yang memiliki gaya belajar yang berbeda-beda tersebut dapat berkembang secara optimal. Adanya berbagai macam inovasi yang dilakukan oleh guru membuat siswa menggunakan berbagai macam gaya belajar di sekolah, sehingga siswa tidak jenuh dalam belajar sehingga kompetensi pengetahuan IPA siswa dapat ditingkatkan. Selain itu, motivasi berprestasi siswa juga berpengaruh terhadap kompetensi pengetahuan IPA tersebut. Susanto (2018: 29) menyatakan bahwa, "motivasi merupakan dorongan, kekuatan, keinginan, yang terdapat dalam diri siswa, yang menyebabkan siswa bertindak atau berbuat, sehingga motivasi berprestasi yang tinggi mendorong siswa untuk fokus pada pencapaian prestasi”. Maka dari itu, siswa yang memiliki motivasi berprestasi tinggi, akan berdampak baik pada kompetensi pengetahuan IPA nya karena siswa cenderung berusaha menerima dan menyelesaikan tugas-tugas dengan sebaik mungkin.

Pujiarti (2013) menyatakan bahwa ada hubungan yang positif dan signifikan antara gaya belajar dengan prestasi belajar siswa kelas V SD Negeri Percobaan 4 Wates Kulon Progo Tahun Ajaran 2012/2013. Keeratan hubungan antara gaya belajar dengan prestasi belajar siswa kelas V SD Negeri Percobaan 4 Wates Kulon Progo Tahun Ajaran 2012/2013 sebesar $22,1 \%$. Persamaan kajian penelitian tersebut dengan penelitian ini yaitu sama-sama mencari 
suatu hubungan dan meneliti gaya belajar. Perbedaannya yaitu pada penelitian Pujiarti memfokuskan pada prestasi belajar, sedangkan penelitian ini memfokuskan pada kompetensi pengetahuan IPA. Selain itu, perbedaanya juga terletak pada tempat penelitian, Pujiarti memfokuskan tempat penelitian di SD Negeri Percobaan 4 Wates Kulon Progo, sedangkan penelitian ini dilaksanakan di SD Negeri Gugus Ki Hajar Dewantara Kecamatan Denpasar Timur.

Penelitian relevan lainnya yaitu penelitian oleh Sulistyarini (2013) menyatakan bahwa motivasi berprestasi berpengaruh positif terhadap hasil belajar IPA siswa kelas IV SD Negeri Celep 5 Sragen Tahun Ajaran 2012/2013 dengan hasil analisis regresi memperoleh nilai $t_{\text {hitung }}>$ $t_{\text {tabel }}(1,734>1,721)$ diterima pada taraf signifikan $10 \%$. Persamaan kajian penelitian tersebut dengan penelitian ini yaitu sama-sama mencari suatu hubungan dan meneliti motivasi berprestasi. Perbedaannya yaitu pada penelitian Sulistyarini memfokuskan tempat penelitian di SD Negeri Celep 5 Sragen, sedangkan penelitian ini dilaksanakan di SD Negeri Gugus Ki Hajar Dewantara Kecamatan Denpasar Timur

\section{Simpulan dan Saran}

Berdasarkan hasil penelitian dan pembahasan, dapat disimpulkan sebagai berikut. 1) terdapat pengaruh yang signifikan gaya belajar terhadap kompetensi pengetahuan IPA kelas $\mathrm{V}$ SD Negeri Gugus Ki Hajar Dewantara Kecamatan Denpasar Timur Tahun Ajaran 2018/2019 dan kontribusinya sebesar 4\%. Hal ini berarti semakin tinggi gaya belajar siswa maka semakin tinggi kompetensi pengetahuan IPA siswa. 2) terdapat pengaruh yang signifikan motivasi berprestasi terhadap kompetensi pengetahuan IPA kelas V SD Negeri Gugus Ki Hajar Dewantara Kecamatan Denpasar Timur Tahun Ajaran 2018/2019 dan kontribusinya sebesar $7,7 \%$. Hal ini berati semakin tinggi motivasi berprestasi siswa maka semakin tinggi kompetensi pengetahuan IPA siswa. 3) terdapat pengaruh yang signifikan gaya belajar dan motivasi berprestasi terhadap kompetensi pengetahuan IPA kelas V SD Negeri Gugus Ki Hajar Dewantara Kecamatan Denpasar Timur Tahun Ajaran 2018/2019 dan kontribusinya sebesar $12,3 \%$. Hal ini berarti semakin tinggi gaya belajar dan motivasi berprestasi siswa maka semakin tinggi Kompetensi pengetahuan siswa.

Sebagai tindak lanjut dari hasil penelitian, maka penelitian ini disarankan kepada (1) Siswa disarankan untuk terus semangat dalam belajar dan terus memotivasi diri agar berprestasi sehingga cepat mengerti dalam menerima pembelajaran dan pencapaian kompetensi pengetahuan IPA dapat terus meningkat. (2) Guru disarankan untuk menggunakan berbagai inovasi dalam pembelajaran yang membuat siswa menggunakan berbagai macam gaya belajar sehingga siswa tidak merasa jenuh dalam mengikuti pembelajaran yang diberikan oleh guru. (3) Kepala Sekolah disarankan untuk selalu memberikan atau memfasilitasi sumber belajar siswa guna menunjang pembelajaran yang ada di sekolah sehingga pembelajaran di sekolah dapat terlaksana dengan optimal dan menghasilkan siswa yang berkualitas. (4) Disarankan kepada peneliti lain agar hasil penelitian ini dapat digunakan sebagai referensi untuk melaksanakan penelitian sejenis atau dapat mengembangkan penelitian ini dengan variabel-variabel yang lain.

\section{Daftar Pustaka}

Agung, A.A Gede. 2012. Metodologi Penelitian Pendidikan. Singaraja: Universitas Pendidikan Ganesha.

Agung, A.A Gede. 2014. Metodologi Penelitian Pendidikan. Singaraja: Aditya Media Publishing.

Agung, A.A Gede. 2016. Statistika Dasar untuk Pendidikan. Yogyakarta: Deepublish.

Arikunto, Suharsimi. 2010. Prosedur Penelitian. Jakarta: PT Rineka Cipta. 
Baharuddin dan Esa Nur Wahyuni. 2010. Teori Belajar dan Pembelajaran. Jogjakarta: Ar-Ruzz Media.

Bire, Josua, dkk. 2014. Pengaruh Gaya Belajar Visual, Auditorial, dan Kinestetik Terhadap Prestasi Belajar Siswa. Kupang: Universitas Nusa Cendana.

Dantes, Nyoman. 2012. Metode Penelitian. Yogyakarta: ANDI.

Deporter, Bobbi dan Mike Hernacki. 2016. Quantum Learning. Bandung: Penerbit Kaifa.

Djaali, H. 2012. Psikologi Pendidikan. Jakarta: PT Bumi Aksara.

Jihad, Asep. 2012. Evaluasi Pembelajaran. Yogyakarta: Multi Pressindo.

Kosasih, E. 2016. Strategi Belajar dan Pembelajaran. Bandung: Penerbit Yrama Widya.

Koyan, I Wayan. 2012. Statistik Pendidikan. Singaraja: Universitas Pendidikan Ganesha Press.

Kurniasih dan Berlin Sani. 2016. Revisi Kurikulum 2013. Jakarta: Kata Pena.

Mulyasa, E. 2006. Kurikulum Berbasis Kompetensi. Bandung: PT Remaja Rosdakarya.

Nurgiyantoro, Burhan. 2016. Penilaian Pembelajaran Bahasa Berbasis Kompetensi. Yogyakarta: BPFE.

Pujiarti, Amin. 2013. Hubungan Gaya Belajar dengan Prestasi Belajar Siswa Kelas V SD Negeri Percobaan 4 Wates Kulon Progo Tahun Ajaran 2012/2013. Yogyakarta: Universitas Negeri Yogyakarta. Tersedia pada https://eprints.uny.ac.id/15771/1/SKRIPSI\%20AMIN\%2009108241017\%20PDF.pdf (diakses tanggal 8 September 2013).

Setyosari, H. Punaji. 2015. Metode Penelitian Pendidikan \& Pengembangan. Jakarta: Prenadamedia Group.

Slameto. 2010. Belajar \& Faktor-Faktor yang Mempengaruhinya. Jakarta: Rineka Cipta.

Sugiyono. 2009. Metode Penelitian Pendidikan. Bandung: Alfabeta.

Sugiyono. 2015. Metode Penelitian Pendidikan. Bandung: Alfabeta.

Sugiyono. 2017. Metodologi Penelitian Pendidikan. Bandung: Alfabeta.

Sukardi. 2012. Metodologi Penelitian Pendidikan. Jakarta: PT Bumi Aksara.

Sulistyarini, Rahmawati Kartika. 2013. Pengaruh Motivasi Berprestasi dan Kebiasaan Belajar Terhadap Hasil Belajar IPA Kelas IV SD Negeri Celep 5 Sragen Tahun Ajaran 2012/2013. Surakarta: Universitas Muhammadiyah Surakarta. Tersedia pada http://eprints.ums.ac.id/24391/12/02. NASKAH PUBLIKASI.pdf (diakses tahun 2013).

Supardi. 2016. Konsep Baru Statistika yang Lebih Komprehensif. Jakarta: Change Publication.

Supardi. 2017. Statistik Penelitian Pendidikan. Depok: Rajawali Pers. 
Suryaningsih. 2015. Korelasi Motivasi Berprestasi dengan Kemandirian Belajar Siswa Kelas IV Sekolah Dasar Se-Gugus 4 Kecamatan Wates Kabupaten Kulon Progo Tahun Ajaran 2014/2015. Yogyakarta: Universitas Negeri Yogyakarta. Tesedia pada https://eprints.uny.ac.id/20158/1/Suryaningsih 11108241078.pdf (diakses tanggal 5 Juni 2015).

Susanto, Ahmad. 2013. Teori Belajar dan Pembelajaran di Sekolah Dasar. Jakarta: Kencana Prenadamedia Group.

Susanto, Ahmad. 2014. Pengembangan Pembelajaran IPS di Sekolah Dasar. Jakarta: Kencana Prenadamedia Group.

Susanto, Ahmad. 2018. Bimbingan dan Konseling di Sekolah. Jakarta: Kencana Prenadamedia Group.

Ulfa, Mareta. 2017. Hubungan Gaya Belajar Terhadap Prestasi Belajar IImu Pengetahuan Sosial Siswa Kelas V SD Negeri 10 Metro Timur. Bandar Lampung: Universitas Lampung. Tersedia http://digilib.unila.ac.id/27248/3/SKRIPSI\%20TANPA\%20BAB\%20PEMBAHASAN.pdf pada (diakses tahun 2017).

Uno, Hamzah B. 2016. Teori Motivasi \& Pengukurannya. Jakarta: Bumi Aksara.

UU RI 2003. Undang-Undang Republik Indonesia Nomor 20 Tahun 2003. Tentang Sistem Pendidikan Nasional. Jakarta: Presiden Republik Indonesia.

Wisudawati, Asih Widi dan Eka Sulistyowati. 2015. Metodologi Pembelajaran IPA. Jakarta: Bumi Aksara.

Yaumi, Muhammad. 2013. Prinsip - Prinsip Desain Pembelajaran. Jakarta: Kencana Prenadamedia Group. 